\begin{tabular}{|c|c|c|c|c|}
\hline & & & & \\
\hline & $\mathrm{H}=\mathrm{I}$ & $0=16$. & Richards. & Germat \\
\hline Nitrogen $\ldots \ldots \ldots \ldots \ldots$ & I 3.93 & I 4.04 & I 4.045 & I 4.04 \\
\hline Osmium $\ldots \ldots \ldots \ldots$ & IS9.6 & I9I.0 & 190.8 & IgI. \\
\hline Oxygen...$\ldots \ldots \ldots \ldots$ & 15.88 & I6.000 & 16.0000 & 16.00 \\
\hline Palladium .............. & 106.2 & 107.0 & 106.5 & 106. \\
\hline Phosphorus...$\ldots \ldots \ldots$ & 30.75 & 31.0 & 31.0 & 31. \\
\hline 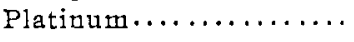 & I93. 4 & 194.9 & I95.2 & I94. 8 \\
\hline 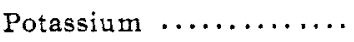 & $3^{8.82}$ & 39.II & 39.140 & 39.15 \\
\hline Praseodymium....... & I 39.4 & 140.5 & 140.5 & 140. \\
\hline 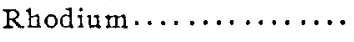 & 102.2 & 103.0 & 103.0 & IO3. \\
\hline Rubidium ............. & 84.75 & 85.4 & 85.44 & 85.4 \\
\hline Ruthenium $\ldots \ldots \ldots \ldots$ & 100.9 & IOI .7 & IOI.7 & IOI.7 \\
\hline ium $\ldots \ldots \ldots \ldots$ & $I 49.2$ & I50.3 & I50.0 & 150. \\
\hline ium $\ldots \ldots \ldots \ldots$ & 43.8 & $44 . I$ & 44. & 44.1 \\
\hline$u m \ldots \ldots \ldots \ldots$ & 78.6 & 79.2 & 79.2 & 79. I \\
\hline Silicon $\ldots . \ldots \ldots \ldots \ldots$ & 28.2 & 28.4 & 28.4 & 28.4 \\
\hline$\ldots \ldots \ldots \ldots \ldots \ldots$ & IO7.I1 & 107.92 & 107.930 & 107.93 \\
\hline$n \ldots \ldots \ldots \ldots \ldots$ & 22.88 & 23.05 & 23. & 23.05 \\
\hline tium $\ldots \ldots \ldots \ldots$ & 86.95 & 87.60 & 87.68 & 87.6 \\
\hline hur................ & 31.83 & 32.07 & 32.065 & 32.06 \\
\hline $1 \mathrm{um} \ldots \ldots \ldots \ldots$ & $18 r .5$ & I 82.8 & $18_{3}$. & I 83. \\
\hline Tellurium............. & I 26.5 & I $27.5 ?$ & I $27.5 ?$ & 127. \\
\hline$u m \ldots \ldots \ldots \ldots$ & I 58.8 & 160. & 160. & $\ldots$ \\
\hline ium $\ldots \ldots \ldots \ldots \ldots$ & $202.6 I$ & 204 . I 5 & 204.15 & 204.1 \\
\hline$u m \ldots \ldots \ldots$ & 230.8 & 232.6 & 233. & 232. \\
\hline Thulium .............. & I69.4 & 170.7 & I70.? & $\ldots$ \\
\hline Tin $\ldots \ldots \ldots \ldots \ldots \ldots$ & II8.I & II 9.0 & II 9.0 & II 8.5 \\
\hline $14 m \ldots \ldots \ldots$ & 47.8 & 48.15 & 48.17 & 48.1 \\
\hline $\operatorname{sten} \ldots \ldots \ldots \ldots \ldots$ & I 82.6 & 184 & $\mathrm{I} 84.4$ & $\mathrm{I} 8_{4}$ \\
\hline $\operatorname{ium} \ldots \ldots \ldots \ldots$ & 237.8 & 239.6 & 240. & 239.5 \\
\hline$n \mathrm{~m} \ldots \ldots \ldots$ & 51.0 & $5 \mathrm{I} .4$ & 51.4 & $5 \mathrm{I} .2$ \\
\hline Ytterbium............. & 171.9 & 173.2 & I73. & I73. \\
\hline$\mu m \ldots \ldots \ldots \ldots$ & 88.3 & 89.0 & 89.0 & 89. \\
\hline$\cdots \ldots \ldots$ & 64.9 & 65.4 & 65.40 & 65.4 \\
\hline Zirconium $\ldots \ldots \ldots \ldots$ & 89.7 & 90.4 & 90.5 & 90.6 \\
\hline
\end{tabular}

\title{
PRELIMINARY COMMUNICATION ON THE CHEMISTRY OF MUCIN.'
}

BY P. A. LEVEXE.

Recelved December 23, 1899 .

THE proteids may be divided into two main groups: First, simple proteids, second, combined proteids. Of the latter the most common are the nucleo-compounds and the mu-

1 Read before the New York Section of the American Chemical Society, November 10, 1899 . 
cins. The mucins at present are considered to be compounds of proteids with carbohydrates. This assumption is based on the fact that all the mucins and allied compounds yield, on prolonged treatment with dilute mineral acids, substances reducing Fehling's solution in the same manner as glucose. The true nature of these substances was, however, unknown to the first workers on mucin.

The first successful attempt to obtain a pure carbohydrate was made in Hoppe-Seyler's laboratory. Landwehr stated that he obtained from various mucins a substance very similar in its properties to gum and named it " animal gum." He did not, however, view mucin as consisting of proteid and animal gum, molecularly combined. In his opinion mucins were only a mixture of the two substances. His views on this latter point were subsequently retracted by the author. After Landwehr almost every investigator working on this subject sought for the same "animal gum," and many claimed to have obtained it. Hammarsten succeeded but once in obtaining from mucin a nitrogen-free substance, which, on heating with mineral acids, was capable of reducing an alkaline copper solution. Loebish asserted that by following the conditions indicated by Landwehr he obtained the same "animal gum" from the mucin of fibrous tissue.

A new series of investigations on the entire question of "aninol gum" was very recently undertaken by Folin in Hammarsten's laboratory. The latter doubting for certain reasons the correctness of Landwehr's statements, followed as closely as possible all the conditions prescribed by Landwehr, the substances thus obtained never being free from proteid material. Instead of "animal gum" he obtained a "mucinalbumose." Most of the other workers investigated only the composition of the various mucins as such, or the "carbohydrates" resulting from heating the mucins with dilute mineral acids.

There is, however, one property of all the mucins, to which sufficient attention has not been directed. The mucins possess very marked acid properties, more distinct than any simple proteid, and, in fact, more than any carbohydrate, which display no acid character whatever. In explanation of the acid properties two assumptions may be made: First, the substance reducing copper (formed on heating with mineral acids), may be an acid 
derivative of some carbohydrate, and secondly, there may be some acid besides the proteid and carbohydrate in the mucin molecule. Loebisch had already noticed that his "animal gum" would decompose carbohydrates, and Hammarsten stated that he could obtain a substance with acid properties from mucins.

The object of this work was to make a thorough study of the acid part of the mucin molecule. My first experiments were made on tendo-mucin obtained according to the method of Chittenden and Gies. The pure mucin was treated for twenty-four to forty-eight hours with a 2 per cent. sodium hydroxide solution and from this solution a substance with acid properties was obtained, by a very simple method, which will be described when the work is completed.

On more detailed examination the substance proved to be nitrogenous. It did not, however, give the biuret reaction, and consequently was free from proteids. On boiling with dilute hydrochloric acid the substance reduced Fehling's solution. The solution of the substance on addition of hydrochloric acid and barium chloride remained perfectly clear, but on boiling yielded a white precipitate. All these properties are peculiar to chrondroitinsulphuric acid. Hence it was natural to assume some relationship between the two substances. Two grams of the substance were heated on a water-bath in roo cc. of 3 per cent. nitric acid until the solution gave no precipitate with alcohol (this consumed about twenty hours). Several volumes of alcohol and ether were then added to this solution. This yielded only an opalescence; upon addition of a few drops of sodium chloride solution, however, a fine white precipitate formed, which gave the barium test for chrondrosin.

The substance gave a precipitate with a solution of Witte's peptone only on addition of acetic acid as long as there was still some of the sodium salt present. When the acid was free from sodium salts, it gave on standing with a neutral albumose solution a flocculent slimy precipitate, resembling genuine mucin. Copper, sodium, and barium salts of the substance were also obtained.

ANALYSIS OF THE COPPER SALT.

$0.35^{8}$ gram of the substance was decomposed with hydrochloric acid; the copper was precipitated with hydrogen sulphide and 
weighed as $\mathrm{CuO} ; 0.0446$ gram $\mathrm{CuO}$, or 9.97 per cent. metallic copper was obtained.

Schmiedeberg found the percentage of copper varying between 9.04 and 10.20 per cent. In all these properties, as well as the copper content, this substance resembles chrondroitinsulphuric acid.

The next question was whether this ethereal or compound sulphuric acid was only a contamination of the mucin, or constituted an integral part of it. Some of the mucin prepared as above was dissolved in 1 per cent. sodium carbonate, and immediately treated as before for the isolation of the acid; only traces were, however, obtained. The residue was washed and redissolved and again treated in like manner; here also only traces were detected. The residue was then thoroughly washed with distilled water until the substance was entirely washed out. The residue was left for twenty-four hours in $200 \mathrm{cc}$. of 2 per cent. solution of sodium hydroxide. It was then treated as above for the isolation of the substance. The yield was a very good one. I also observed that the acid can be split off from mucin on digesting the latter on the water-bath with addition of a few drops of hydrochloric acid. On digestion with pepsin-hydrochloric acid the mucin also yielded the same acid even after twenty-four hours of digestion. After three weeks of digestion part of the mucin, however, remained undissolved. The investigation into the nature of the residue, as well as of the proteoses thus formed, has so far not been completed.

The next question was whether only the tendo-mucin is a compound of an ethereal sulphuric acid, or whether all the mucins and mucoids have the same composition. The investigation before us thus far embraces only the submaxillary mucin and the substance of a mucoid carcinoma. The submaxillary mucin was obtained by the following method: Freshly removed glands were placed in ether immediately after the death of the animal, and then brought to the laboratory. There they were minced in a chopping machine and allowed to macerate with distilled water for twenty-four hours (large quantities of chloroform being added to keep the tissue from decomposing). The extract was then strained through gauze, well shaken with ether in separatory funnels, and left in the latter for twenty-four hours. 
This process caused all the tissue particles and the fat to collect on the surface, the lower layer remaining perfectly clear. It was then filtered and treated for mucin according to the method of Hammarsten. The substance was redissolved and reprecipitated twice. This mucin was treated in the same way as the tendomucin for the ethereal sulphuric acid. But instead of the latter a substance was obtained very similar to that obtained by Folin in Hammarsten's laboratory, and which he called mucinalbumose.

After several futile attempts to obtain the acid free from proteids I finally obtained positive results by the following method: The mucin was digested for one hour in a Koch sterilizer with o.I per cent. hydrochloric acid solution. The solution, being then neutralized with sodium hydroxide, was treated with large quantities of alcohol. The precipitates thus formed were treated with 5 per cent. sodium hydroxide and allowed to stand over night. This solution was treated in two different ways, each yielding positive results: (I) The solution was treated with Brucke's reagent and hydrochloric acid. The filtrate did not give any precipitate on addition of alcohol and ether. If, however, a sufficient quantity of sodium hydroxide was added previously to the alcohol to render the solution slightly alkaline, a yellowish precipitate was formed very similar to that of the sodium salt of the ethereal sulphuric acid. The precipitate was redissolved in dilute sodium hydroxide solution, filtered and reprecipitated with alcohol. The substance thus obtained precipitated an acid solution of albumose, reduced Fehling's solution on boiling with hydrochloric acid, and on addition of hydrochloric acid and barium chloride gave a precipitate only upon heating. It was nitrogenous and did not give the biuret reaction. There was not enough of the substance to attempt the chrondrosin test.

In another experiment phosphotungstic acid was used instead of Brucke's reagent. The result was the same.

From this may be concluded that the submaxillary mucin contains in its molecule a substance which is either chondroitinsulphuric acid or closely related to it. The investigation of a mucoid carcinoma by the same method as the submaxillary mucin revealed the presence of a similar substance. The study 
of ovomucoid, mucoid of the thyroid gland and of a mucoid tumor is now in progress.

I was prompted to make the present communication by the fact that about ten days ago an article appeared in Hoppe-Seyler's Zeitschrift. The author analyzed an ovarial mucoid and found a substance similar to chondroitinsulphuric acid. His findings on the latter mucoid coincide with mine on several mucins and justify the conclusions I was ready to draw from my work, that mucins are not simple compounds of proteids and carbohydrates, but are proteid derivatives of an ethereal sulphuric acid.

I consider it premature at this moment to state positively the nature of this combination.

\title{
BIBLIOGRAPHY.
}

Chittenden and Gies: Journal of Experimental Medicine, Vol. I.

Folin: Ztschr. phys. Chem., Bd. 23.

Hammarsten : Pfluger's Arch., Bd. $3^{6}$.

Landwehr: Ztschr. physiol. Chem., Bd. 5, 6, 8, 9, PHïger's Arch., Bd. 39. Loebisch: Ibid., Bd. Io.

Hanzer: Ibid., Bd, 28.

Schmeideberg: Arch. exp. Pathol. and Pharm., Bd. 28.

[CONTRIBUTION FROM THE CHEMICAL DIVISION, U. S. DFPARTMENT OF Agriculture, No. 36 . Sent by H. W. Wiley.]

\section{THE DETERMINATION OF GLYCOGEN AND RELATIVE QUANTITIES OF GLYCOGEN IN DIFFERENT PARTS OF THE FLESH OF A HORSE.}

\author{
BY J. K. HAYWOOD. \\ Received January $t 6,5900$.
}

\begin{abstract}
GREAT many methods have been proposed for the estimaA tion of glycogen, 'but on trying them I found that nearly all were open to some serious objection, which rendered their employment either entirely out of the question or the results obtained very doubtful. I have, therefore, worked out a method which, although not new in principle, is new in many of the details which go to making up a fairly accurate and speedy procedure. But first I will speak of some of my preliminary experiments to show future workers in this field, at least, what not to do.
\end{abstract}

1 Wiley's "Principles and Practice of Agricultural Aualysis", 3. 554. 